\title{
Cooking and Maslow's Hierarchy of Needs: A Qualitative Study of Home Economics Students' Perspectives
}

\author{
Zian Perater \\ Dustin Caintic \\ Luigi Canencia \\ Michael Evanoso \\ Shaira Macabuat \\ John Erno \\ Vincent Elan \\ Cathy Jane Lapinig \\ Jullan Ortalla \\ Razonable \\ Jef Bangkas \\ March 2019 \\ Correspondence: \\ Jullan Ortalla \\ Team Leader \\ University of Immaculate Conception \\ Annex Campus \\ Bonifacio St., Davao City 8000 \\ Davao del Sur, Philippines \\ (082) 2271573 \\ (082) 2273794
}




\begin{abstract}
The point of this investigation was to look at the impact of cooking as an interest movement on the gourmet specialists, in the specific situation of Maslow's Hierarchy of Needs. The after effects of the examinations demonstrate that Maslow's hypothetical develop is an applicable and legitimate setting for understanding the impact of cooking on the culinary experts. Subsequently we found that cooking bear's novice gourmet experts a feeling of control, of social and ethnic belongingness, interfacing with family's underlying foundations; it fortifies self-adequacy and social regard. The researchers additionally discovered that cooking enables beginner gourmet experts to express their innovativeness and like themselves. At last, the examination demonstrates that as seen by novice gourmet specialists, it has restorative components, for example, a diminish feeling of time, adjusted cognizant dimension and solid exotic boost. The alternative of serving the cooked item was additionally seen as a restorative variable in cooking.
\end{abstract}

Keywords: cooking, Maslow's hierarchy of needs, amateur chefs, effects of cooking 


\section{INTRODUCTION}

\section{Background of the Study}

Wrangham et al., (1999), said it is expected that the point of this action was to fulfill human physiological requirements. Throughout the years, cooking has turned into a focal component in Western culture, related to personal satisfaction and extravagance. Beoku-Betts (1995), in the previous decades, the noteworthiness ascribed to the action of home cooking has expanded. According to Harvard University (2009), while cooking has for some time been contended to improve the eating regimen, the nature of the improvement has not been all around characterized. Almas (2006), as the researcher additionally, guarantees that nourishment and cooking are altogether present in different media and the universe of recreation culture (cooking appears, assigned sustenance channels, newspapers, magazines, notices, and movies) advancing "refined" cuisine. According to Zusman-Asher (1997), managing the compatibility between recreation time exercises and identity, confirm the above case. It has appeared a positive connection between happiness with the relaxation movement and general satisfaction with life. Maslow's (1971), expected the accompanying five, progressively orchestrated dimensions of requirements: physiological necessities, secure requirements, love and belongingness needs, regard needs and selfrealization needs. Maslow's (1962), Cooking as a recreation time movement offers a captivating potential to add to the amateur gourmet specialists' prosperity. Sidenvall's (2000), study's outcomes bolster that cooking fulfills secure requirements. According to Starr-Sered (1988), they additionally revealed cooking enabled them to deal with their youngsters' physical, and social needs. As indicated by Carl Roger (2018), self-realization is a procedure of developing and creating as an individual to accomplish the potential. As for Kendra Cherry (2018), in Maslow's Hierarchy of needs trust that these requirements are like senses and assume a job in rousing conduct. Physiological, security, social, and regard needs are insufficiency needs, which emerges because of hardship. These dimensions are imperative to evade upsetting sentiments and results. Maslow's (1970) 
hierarchical hypothesis of a person's inspiration in each content in introductory psychology. It has gotten moderate exploratory support (Wicker et al., 1993) in predicting how people mature. Sirgy (1986) has recommended that it can additionally portray how countries create and improve their satisfaction. Maslow arranges all of human endeavoring as an endeavor to fill one.

According to Lockwood (2010), motivation is characterized as the mental powers that decide the course of an individual's, just as a person's persistence in the face of obstacles. Motivation provides a goal that the employee works towards, thereby giving the employee a direction to follow. According to Yao, Franco, \& Hechanova (2005), another study on what motivates the Filipino worker reported that the majority of the specialists are driven by intrinsic motivators rather than extrinsic motivators. As per Hofstede (1980), there are different hypotheses that depict what motivates workers as well as the process by which motivation occurs. However, these theories were developed using a Western perspective and in advance economies; and there is increasing evidence that the hypothesis may not be totally applicable across all cultures.

The point of the existing study was to inspect the impact of cooking as a hobby activity on the chefs, with regards to Maslow's Hierarchy of Needs. The result of the investigation demonstrates that Maslow's theoretical construct is applicable and a valid context to understand the effect of cooking on the chefs. Along these lines the researchers found that cooking bears beginner gourmet specialist a feeling of control, of social and ethnic belongingness, associating with family's underlying foundations, it strengthens self-viability and social regard. The researchers found that cooking enables the amateur chef's to express their creativity and feel satisfied with them. Lastly, the examination demonstrates that the amateur chefs, has therapeutic elements, for example, a diminished feeling of time, changed cognizant level and concrete erotic boost. The choice of serving the cooked item as a restorative in cooking.

Based on the previous study in Maslow's Theory, preparing food helps the amateur chefs to express their physiological needs. Also the vast majority of these 
investigations have been undertaken to understand Maslow's Hierarchy of Needs. As clear from the examinations, there are a few researchers' who conducted Maslow's chain of order, the result of the examination demonstrates that cooking satisfies secure necessity, moreover ensures that sustenance and cooking coincided in various types of world amusement culture, the comprehension of the buyer's needs, needs and needs depends upon the degree of an individual's goad has made Maslow's hierarchy of leadership of prerequisites speculation get the notoriety of importance, in dislike of the amazing confirmation discrediting the nearness of the said requests. (Almas 2006; Sidenvall's 2000; Solomon 2009) The Scope of the said study Maslow's Hierarchy of Needs covers the University of Immaculate Conception particularly home economic students, furthermore there are few studies on Maslow's chain of command. A comprehensive study on understanding Maslow's chain of command is crucial to correctly extract and better understand the physiological needs of a chef.

The vast potential of Maslow's Hierarchy of Needs is to appropriately utilize by adopting a phenomenological approach in gathering data's, which requires a better understanding of the said hierarchies. This investigation aims at fulfilling the previous research gap in emerging Maslow's chain of command. This study starts with analyzing the physiological needs of the human being. Understanding Maslow's Hierarchy of Needs can help in nourish the understanding of physiological needs.

"Self-realization" speaks to an idea got from Humanistic mental hypothesis and, explicitly, from the hypothesis made by Abraham Maslow. Self-completion, as per Maslow, speaks to development of a person toward satisfaction of the most noteworthy needs; those for significance throughout everyday life, specifically. Carl Rogers additionally made a hypothesis involving a "development potential" whose point was to incorporate compatibly the "genuine self" and the "perfect self" along these lines developing the rise of the "completely working individual". It was Maslow, in any case, who made a mental chain of importance of necessities, the satisfaction of which hypothetically prompts a finish of satisfaction of "being 
values", or the requirements that are on the most elevated amount of this progressive system, speaking to significance.

\section{Purpose of the Study}

There five levels of Maslow's Hierarchy of Needs are: Physiological Needs, Safety and Security Needs, Social Needs, Esteem Needs and Self-Actualizing Needs.

The objective of this research is to enlarge the knowledge of other individuals about the sentiments of others as they cook. Numerous individuals judged someone dish without knowing their emotions or without understanding that they are hurting somebody. Along these lines, through this study it will help you understand that it is very vital that we think what other individuals feel when the circumstance goes when we taste what they cook for us since we do not recognize what is the struggle they are experiencing or how cheerful they are as they cook.

\section{Research Questions}

This question is dedicated to the people who are selected of the researchers for which are the SHS chefs of UIC. How they respond to this can depend on how they proceed in the Home Economics track that they chose. The question is:

1. What is the effect of cooking as a hobby activity on Home Economics students, in the context of Maslow's Hierarchy of Needs?

\section{Theoretical Lens}

This phenomenological case study was anchored on several theories such as the theory of self-actualization, self-esteem and human motivation to examine the impact of preparation as a hobby activity on the chefs, within the context of Maslow's Hierarchy of needs.

The primary theory in this study is the theory of self-actualization, according to Maslow, self-actualization could be a method by that people might ascend a 
hierarchy of needs that is linear as critical dialectical. The higher levels of this hierarchy are reached by psychologically strong and healthy self-actualizing people. Also, Maslow contends that these self-actualizing people are extremely artistic and demonstrate a capability to resolve dichotomies inherent in final contraries, like life versus death and freedom versus philosophical theory, as examples. This discussion doesn't challenge Maslow's theory as much as it extends the ideas postulated by him. This theory was expounded to our study as a result of self-actualization describes the will that ends up in the conclusion of one's full potential. In other words, that person has become everything he or she is capable of changing into. This realization of potential will occur in many ways however typically includes the accomplishment of sound psychological health and a tough sense of fulfillment.

Self-esteem continues to be one of the most commonly researched concepts in Social Psychology (Baumeister 1993; Mruk 1995; Wells and Marwell 1976; Wylie 1979). While generally conceptualized as a part of the self-concept, to some, self-esteem is one of the most major parts of the self-concept. Indeed, for a sometime, so much attention was given to self-esteem that it seemed to be synonymous with "self-concept" in the literature on the self (Rosenberg 1976, 1979). This focus on self-esteem has mostly been due to the association of high self-esteem with some of positive outcomes for the individual and society as a whole (Baumeister 1993; Smelser 1989). This includes a wide-spread belief that raising an individual's self-esteem (especially that of a child or adolescent) would be beneficial for both the individual and society as a whole. This theory was expounded to our study as a result of vanity refers to an individual's sense of his or her price or worth, or the extent to that someone values, approves of, appreciates, prizes, or likes him or herself.

Lastly, the Theory of Human Motivation (1943) the American psychologist Abraham Maslow projected that healthy persons have a particular variety of needs, which these needs are organized in a very hierarchy, with some needs (such as physiological and safety needs) being additional primitive or basic than others 
(such as social and ego needs). Maslow's alleged 'hierarchy of needs' is commonly conferred as a five-level pyramid, with higher needs returning into focus just the once lower, additional basic needs are met.

Therefore, we can say that this study would be anchored to three validated and related theories regarding the research issue.

\section{REVIEW OF RELATED LITERATURE}

\section{Maslow's Hierarchy of Needs}

Abraham Maslow built up a hypothesis on the hierarchy of human needs. Maslow's hierarchy is frequently illustrating as a pyramid- much like in a food pyramid where progressively critical nutritional categories are at the base of the pyramid and lesser or unnecessary groups further to the best. There are five "needs" in the pyramid of Maslow's progressive system, and the necessities rise from the most essential human needs to larger amount needs. Maslow named the five levels of need a physiological, safety, love/belonging, esteem, and selfactualization. Maslow isolated the requirements into two groups: physiological, security, love/belonging, and esteem are all deficiency needs; people must fulfill the majority of their lack needs before they can accomplish self-completion. Selfactualization is a development need, and Maslow demonstrated that accomplishing this is a definitive objective of the chain of importance of requirements. Deficiency needs may incorporate nourishment, water, and asylum; while development needs may incorporate objective fulfillment and selfimprovement.

Maslow's hierarchy of needs can be a helpful structure for your exploration on the off chance that you are planning to consider human inspiration or conduct. Ordinarily, according to Maslow's order, people's dimensions of inspiration will diminish as they address lack issues. Be that as it may, inspiration will increment as they accomplish development needs. The fulfillment of shifting insufficiency and development needs impacts human conduct, as people will act as needs be on the off chance that they have needs that are not being met.

\section{The Levels of Maslow's Hierarchy of needs}


The most basic human needs are appeared at the underside of the hierarchy, and these are the physiological drives that ensure survival, together with the prerequisite for air, nourishment, water, and rest. Our physiological needs are then trailed by our wellbeing needs that grasp insurance, security, law, solidness, and security for our valuable ones

Expecting the central layer of the hierarchy are our relationship needs or the will for love and belonging; this level incorporates the necessity for family, love, friendship, and sexual closeness. Presently we have the esteem needs that embrace vanity, certainty, notoriety, and regard for oneself and from others. At the most noteworthy of the pecking order or pyramid are simply the needs associated realization, that alludes to "the healing power in psychotherapy - man's inclination to complete himself to end up his potentialities...to express and initiate every one of the limits of the life form" of Carl Rogers the man of science (1902-1987). Examples of self-actualization embrace expressing one's individuality, creativity, the quest for spiritual enlightenment, the pursuit of information, and also the want to be part of society and/or a community. In order to progress through the levels of needs, we have a tendency to should satisfy the fundamental physiological wants. This is somewhat obvious, however unless we've got food, sleep, shelter, etc., we have a tendency to do not have the energy or time to meet our more complex, yet secondary needs. After we are incapable of finding the time and/or energy for these further needs, due to inability to effectively and efficiently satisfy our physiological needs, we are more likely to experience some negative feeling.

As per Daniel Schacter and his associate teachers of Psychology at Harvard (2011) express that after we can't value our potential, because of these troubles, or we tend to carry on with an actual existence inconsistent with our abilities, we tend to are less certainly to be glad than individuals that convey the products a harmony between their objectives and furthermore the lives they accomplish. For instance, on the off chance that we tend to demonstrate some intrinsic brandishing capacity, anyway we tend to can't accomplish our essential 
needs, this potential can go hidden, as we have lacking physical and mental assets offered to United States.

As indicated by Henry Gleitman, and his partner educators of Psychology at Pennsylvania, Stanford and Reed school (2011), conveyed what needs be completion is "...the full acknowledgment of one's potential, and of one's 'actual self' ". Thusly, steady with Maslow's hypothesis of human inspiration, acknowledgment, or genuine bliss as a person's being (over various creatures), is accomplished after we can comprehend our actual potential, anyway this is frequently exclusively potential after we have with progress thought about our fundamental, physiological needs.

\section{Personal Development and Self-Actualization of Students in the New Environment}

Abraham Maslow (1943) said, manufactured a hierarchical pyramid relationship for human needs. At the base are fundamental physical needs like nourishment and sanctuary. The best is self-actualization. Self-actualization alludes to the desire for self-satisfaction, in particular, to the tendency for them to become actualized in what they are potential. This tendency might be communicated as the aching to end up increasingly more what one is, to end up everything that one is fit for getting to be.

According to Gleitman et.al, (1969), self-actualization is at the highest point of Maslow's hierarchy of needs becoming "completely human" development or self-actualization and is viewed as a piece of the humanistic way to deal with identity. Humanistic psychology is one of a few techniques utilized in brain research for contemplating, understanding, and assessing identity.

As per Frank, 1970, some argue that once these requirements are connected, an individual is ready for self-actualization. Others keep up that there are two additional stages an individual must advancement through before selfactualization can happen. These incorporate "the cognitive needs", where an individual will desire knowledge and a comprehension of their general 
surroundings, and "the aesthetic needs" which incorporate a requirement for "symmetry, order, and beauty". When every one of these necessities is fulfilled, the last phase of Maslow's hierarchy-self-actualization—can occur.

According to the study of Saul McLeod, refreshed 2018 Maslow's hierarchy of necessities is an inspirational hypothesis in brain research containing a fivelevel model of human needs, frequently delineated as progressive dimensions inside a pyramid.

\section{Maslow's Hierarchy of Needs: Deficiency needs vs. Growth needs.}

From the base of the order upwards, the necessities are: physiological, wellbeing, love and having a place, regard, and self-completion. Needs let down in the chain of command must be fulfilled before people can take care of requirements higher up.

Maslow's chain of command of necessities five phase pyramid Insufficiency needs versus development needs. This five-arrange model can be divide into lack of needs and development needs. The initial four dimensions are every now and again implied to as lack needs (D-needs), also, the best measurement is known as improvement or being needs (B-needs). Inadequacy needs emerge because of hardship and are said to rouse individuals when they are abandon. Likewise, the inspiration to satisfy such needs will wind up more grounded the more drawn out the term they are refused. For instance, the more drawn out an individual abandons nourishment, the more eager they will move toward becoming.

As per Maslow (1943) says, at first expressed that people must fulfill lower level shortfall needs before advancing on to meet more raised amount development needs. In any case, he later cleared up that fulfillment of necessities isn't an "all-or-none" wonder, conceding that his prior articulations may have given "the bogus impression that a need must be fulfilled 100 percent before the following need rises" (1987, p. 69). 
At the point when a deficiency need has been 'pretty much fulfilled it will leave, and our exercises turn out to be always planned towards meeting the following arrangement of requirements that we presently can't seem to fulfill. These then turn into our remarkable needs. Be that as it may, development needs to keep on being felt and may even end up more grounded once they have been locked in. Maslow's chain of command of necessities five phase pyramid demonstrating lack needs and development needs Development needs don't come from an absence of something, yet rather from a longing to develop as an individual. When this development needs have been reasonably satisfied, one might most likely achieve the largest amount called self-completion.

The individual is proficient and wants to climb the chain of importance toward a dimension of self-realization. Tragically, advance is frequently disturbed by an inability to meet lower level needs. Beneficial encounters, including separation and loss of work, may make an individual vary between dimensions of the chain of command.

Along these lines, not every person will travel through the progressive system in a uni-directional way however may move forward and backward between the diverse kinds of requirements. The first progression of necessities five-arrange display incorporates: Maslow $(1943,1954)$ expressed that individuals are persuaded to accomplish certain requirements and that a couple of requirements exceed others. Our most central need is for physical survival, and this will be the principal thing that rouses our conduct. When that dimension is satisfied the following needs is the thing that propels us, etc.

1. Physiological necessities - these are natural prerequisites for human survival, for example, air, sustenance, drink, cover, attire, warmth, sex, rest. If these necessities are not satisfied the human body can't work ideally. Maslow considered physiological requirements the most imperative as the various needs turned out to be auxiliary until these necessities encountered. 
2. Wellbeing needs - assurance from components, security, request, law, solidness, opportunity from dread.

3. Love and belongingness needs - after physiological and security needs have been satisfied, the third dimension of human needs is social and includes sentiments of belongingness. The requirement for relational connections rouses conduct Models incorporate kinship, closeness, trust, and acknowledgment, accepting and giving love and love. Affiliating, being a piece of a gathering (family, companions, work).

4. Regard needs - which Maslow ordered into two classes: (I) regard for oneself (nobility, accomplishment, authority, freedom) and (ii) the craving for notoriety or appreciation from others (e.g., status, glory). Maslow demonstrated that the requirement for appreciation or reputation is most imperative for youngsters and teenagers and goes before authentic confidence or poise.

5. Self-realization needs - acknowledging individual potential, selfsatisfaction, looking for self-awareness and pinnacle encounters. A craving "to wind up all that one is fit for becoming"(Maslow, 1987, p. 64).

Maslow's progressive system of necessities five phase pyramid Maslow placed that human needs are masterminded in a chain of command: "It is very evident that man lives by bread alone - when there is no bread. In any case, the final product for man's wants when there is a lot of bread and when his midsection is continually filled? Without a moment's delay other (and "higher") needs to develop and these, instead of physiological appetites, overwhelm the life form. What's more, when these are fulfilled, again new (and still "higher") needs rise, etc. What we mean by saying that the essential human needs are composed into a pecking order of relative prepotency" (Maslow, 1943, p. 375).

Maslow kept on refining his hypothesis dependent on the idea of a progression of requirements more than a very long while (Maslow, 1943, 1962, 1987). 
The structure of his chain of importance, Maslow (1987) suggested that the request in the progressive system "isn't so inflexible" (p. 68) as he may have proposed in his before depiction. Maslow noticed that the request of necessities possibly adaptable dependent on external conditions or individual divergence. For instance, he takes note of that for a few people, the requirement for confidence could actually compare to the need for adoration. For other people, the requirement for innovative satisfaction may override even the most fundamental needs.

Maslow (1987) likewise called attention to that most conduct is multipersuaded and noticed that "any conduct will, in general, be controlled by a few or the majority of the fundamental needs all the while as opposed to by just a single of them" (p. 71). Chain of significance of necessities summation: Hierarchy of Needs Summary

(a) Individuals are moved by a chain of significance of necessities.

(b) Needs are sorted out in a series of command of prepotency in which increasingly essential wants should be basically met (as opposed to all or none) preceding higher necessities.

I The request of necessities isn't inflexible yet rather might be adaptable dependent on outside conditions or individual contrasts.

(d) Most conduct is multi-persuaded, that is, at the same time controlled by more than one fundamental need. The importance of requirements notes that Maslow's $(1943,1954)$ five-arrange show has been extended to incorporate intellectual and stylish needs (Maslow, 1970a) and later surprising quality needs (Maslow, 1970b).

\section{The Expanded Hierarchy of Needs}


Changes to the first five-organize display are featured and incorporate a seven-arrange show and an eight-arrange demonstrate; both created amid the 1960s and 1970s.

1. Natural and physiological needs - air, nourishment, drink, cover, warmth, sex, rest, and so on.

2. Wellbeing needs - insurance from components, security, request, law, steadiness, and so forth.

3. Love and belongingness need - kinship, closeness, trust, and acknowledgment, accepting and giving warmth and love. Affiliating, being a piece of a gathering (family, companions, work).

4. Regard needs - which Maslow ordered into two classes: (I) regard for oneself (pride, accomplishment, dominance, freedom) and (ii) the longing for notoriety or admiration from others (e.g., status, esteem).

5. Subjective requirements - learning and comprehension, interest, investigation, the requirement for significance and consistency.

6. Stylish necessities - gratefulness and look for excellence, balance, structure, and so on.

7. Self-completion needs - acknowledging individual potential, selfsatisfaction, looking for self-improvement and pinnacle encounters.

8. Surprising quality needs - An individual is modivated by qualities which rise above past the individual self (e.g., mysterious encounters and certain encounters with nature, stylish encounters, sexual encounters, administration to other people, the quest for science, religious confidence, and so on.).

Maslow's progressive system of necessities eight phase pyramid Selfrealization Rather than concentrating on psychopathology and what turns out badly with individuals, Maslow (1943) planned an increasingly positive record of human 
conduct which concentrated on what goes right. He was keen on human potential, and how we satisfy that potential.

Therapist Abraham Maslow (1943, 1954) expressed that human inspiration depends on individuals looking for satisfaction and change through selfimprovement. Self-realized individuals are the individuals who were satisfied and doing all they were able to do.

The development of self-completion (Maslow, 1962) alludes to the requirement for self-improvement and disclosure that is available all through an individual's life. For Maslow, an individual is continually 'getting to be' and never stays static in these terms. In self-realization, an individual comes to locate a significance to life that is critical to them.

As every individual is interesting, the inspiration for self-realization drives individuals in various ways (Kenrick et al., 2010). For a few people, self-completion can be accomplished through making gems or writing, for others through the game, in the classroom, or inside a corporate setting.

According to Maslow (1962), trusted self-completion could be determined through the idea of pinnacle encounters. This is happens when an individual encounters the world precisely for what it is, and there are sentiments of rapture, delight, and marvel.

Note that self-completion is a consistent procedure of ending up as opposed to an ideal state one compasses of a 'glad ever after' (Hoffman, 1988). Maslow offers the accompanying depiction of self-completion:

It alludes to the individual's craving for self-satisfaction, to be specific, to the propensity for him to wind up realized in what he is possible.

The particular structure that these necessities will take plainly moves incredibly from individual to individual. In one individual it might appear as the craving to be a perfect mother, another it might be communicated physically, in still 
another it might be communicated in painting pictures or in developments' (Maslow, 1943, p. 382-383).

Attributes of self-completed individuals In spite of the fact that we are all, hypothetically, equipped for self-completing, the majority of us won't do as such, or just partially. Maslow (1970) evaluated that just two percent of individuals would achieve the condition of self-completion. He was particularly inspired by the attributes of individuals whom he considered to have accomplished their potential as people.

\section{METHODOLOGY}

\section{Research Design}

This study is a qualitative study which made use of a phenomenological approach to collect data. The phenomenological approach concerns with the understanding and decoding the meaning that participants withhold to their everyday lives (De Vos, 1998). The qualitative approach focuses only on the qualities of human behavior (Ferrero, Mouton, Puth, Schurink, 1988). The goal of such method is not to generalize yet to understand and interpret the meanings and intentions that underlie everyday human actions (Bailey, 1987; Bogdan \& Taylor, 1975; De Vos, 1998; Ferreira et. Al., 1988).

Qualitative design deals with data that is primarily verbal and derives meaning from the participant's stand and also aims to understand meaning that people attach to everyday life (Bless \& Higson-Son, 1995; De Vos, 1998). The qualitative approach is appropriate for this study because the data gathered and used focuses on the participants' subjective experiences on the process of disclosure and the way they understand them. Marshall \& Rossman (1995) further outline that the qualitative approach to research is uniquely suited to uncovering the unexpected and to exploring new avenues. 


\section{Sampling Method}

Purposive, which is a non-probability sampling method and it occurs when "elements selected for the sample are chosen by the judgment of the researcher. Researchers often believe that they can obtain a representative sample by using a sound judgment, which will result in saving time and money" (Black, K., 2010). The researchers purposively selected participants who have adequate knowledge to supply data that is related to the study.

\section{Participants}

After prospective participants were identified, the researcher approached and invited them to take part in the study. They were presented with the information sheet and were further knowledge about their right to refuse participation was voluntary. When they agreed to participate, they were also made aware of their right to withdraw from partaking in the interview. They were further informed that the information that they provided in the interviews would also be handled with confidentiality; they were not required to disclose their identifying details. Finally, they were presented with consent forms for their participation and for the audio tape recording that they signed to give their consent.

The researchers have chosen six purposively participants aged 16-18 who voluntarily give their consent to take part in In-Depth Interview (IDI). Of this six participants, all of them are in St. Veronica (one male and one female), St. Martha (one male and one female) and St. Nicholas (one male and one female). All of these six students participated in the In-Depth Interview (IDI). The criteria for inclusion were: engaging in cooking by choice and cooking at least five hours a week.

\section{Research Instrument}

In this phenomenological study, the research questions were well formulated by the researchers. The questions will undergo first with the evaluation and validation process, conducted by the validator Mr. Joseph Dave M. Pregoner. 
After the validation, the questions will be pilot tested. The instrument which will be utilized in this qualitative phenomenological study is interview questions and will be recorded for authenticity purposes. The questions are written and asked in English and they can use the language they were comfortable in order for them to freely express themselves without uncertainty.

\section{Data Collection Method}

The data was collected using face to face individual interview schedule. According to Ferreira et al. (1998), interviewing is a very significant data collection instrument. The interviews were semi-structured, that is, a list of questions and issues to be discussed was prepared prior to the interview. Semi-structured interviewing gave room for probing for clarification and further discussion of important and relevant issues that arose during the interviews. Where necessary, questions were elaborated to suit the participant. Face-to-face interview enabled the researcher to read the non-verbal communication and reactions, which proved to be helpful in the analysis of the data. The interviews were audiotaped and later transcribed.

Bogdan \& Taylor (1975) listed acceptance and understanding as part of the basic principles of unstructured interviewing. This proved to be a valuable aspect of the rapport building between the researcher and the participants. It was also evident that some of the participants appear encouraged by the researcher's nonjudgemental attitude towards them. At the same time, the researchers were cautious of the emotional involvement that could "affect the validity and the reliability of the data" (Ferreira, et al., 1988: 147). Bogdan \& Taylor (1975) added that it is the interviewer's responsibility to create an ambiance in which participants will feel comfortable enough to talk freely and openly. This was achieved by allowing participants to take part in choosing an appropriate and conducive venue for the interviews. 


\section{Data Analysis Method}

Results were analyzed using the thematic content analysis method. Ezzy (2000) describes this method of statistical analysis as a way of analyzing facts by organizing it into classes on the groundwork of themes, ideas, or similar features. The procedures employed are in particular designed to limit and categorize huge portions of data into more appropriate meaningful devices for interpretation (Singleton, 1997). The steps used in creating themes had been informed by Marshall \& Rossman (1989) in De Vos (1998) and included the following procedures:

\section{Organizing Data:}

The transcribed data was repetitively read through for the researcher to be familiar with the data they are presenting to.

\section{Generating Categories, Themes, and Patterns:}

The researcher then identified the most important themes, recurring ideas, and patterns of belief, which assisted with the integration of the results. This stage is required for creative and analytical thinking. The process of category generation involved noting patterns in the research participants. As categories of meaning emerged, the researcher searched for those that were internally consistent but distinct from each other. Patterns, themes, and categories were uncovered.

\section{Testing Emergent Hypotheses:}

The researchers evaluated the credibility of these developing hypotheses and trying them out as an opposition to the data when categories and patterns between them became apparent. This involved evaluating the data for their informality adequacy, credibility, usefulness, and centrality. 


\section{Searching for Alternative Explanations:}

As the categories between them emerged in the data, the researcher engaged in challenging the patterns that seemed apparent. Alternative explanations were described until the researcher reached the explanations that are acceptable and reasonable.

\section{Report the results:}

By reporting the outcomes report, the researcher offers accurate interpretations and meaning to the huge amounts of raw data acquired.

\section{Trustworthiness of the Study}

As this qualitative case study research was conducted, the researchers presented a letter to the six (6) participants. These letters contain the agreement that whatever data accumulated will be utilized only for the purpose of the study and will be treated with utmost confidentiality. In order to establish trustworthiness, research should have the credibility, transferability, dependability, and confirmability. In terms of validity, the researchers must be confident that this research is valid and accurate since they were able to identify correct operational measures for the concepts being contemplated (Pandey and Patnaik, 2014) which in this case is the interview since interview is very useful when it comes to getting the background of the participants and it can give accurate information about the topic. (McNamara, 1999). The researchers were confident in terms of the credibility of the outcome of this research since the six (6) participants are from the strand TVL specifically the Home Economics students who undergo cooking. The researchers were aware of the ethical consideration in interviewing the participants. The participants can express themselves without any disturbance from the researchers. Lincon and Guba (1985), assert that it is the researchers' duty to provide enough contextual information and background about the conducted research to provide transferability. To establish transferability, the researchers will provide an in-depth description; a term coined by Geertz (1973) which says that a researcher should not only have legitimate information but also 
rich commentary and interpretations. The researchers will provide accurate and enriched detail, on the account of filed experiences. To establish dependability, according to Lincon and Guba (1985), a researcher should employ inquiry audit. In this research, we will have an outsider researcher who is not included of the research team to examine and observe both the process and the outcome of the research study (Lincon and Guba, 1985). The outsider researcher will explain in full detail how data was obtained throughout the research, how categories were obtained, and how decisions were made throughout the research or inquiry. The point of doing this is to evaluate the accuracy and to evaluate whether the interpretations, conclusions, and findings are supported by the collected information. To establish conformability, the researchers were sure that any form of biases is not tolerated and done throughout the inquiry. The way of asking questions was addressed with the utmost respect. The researchers assure that whatever information gathered in this research are not fake and falsified. After transcribing their responses, the participants examined and checked it and then they are asked to sign on the lower right portion if everything wrote was factual as a sign of authenticity. Lastly, the researchers assured the participants that their identities will be confidential.

\section{Ethical Considerations}

After the participants agreed to participate in our study, informed consent was sought from them. This was achieved by reading with the participants both informed consents of participation and tape-recording. They were also asked to sign in order for their consent to be permitted. Participants were informed of the confidentiality clause. This implies that the dignity of a subject should be valued and respected. Therefore, it was important that participants had no doubt that any information provided would be regarded as confidential information and would only be accessed by the researcher and the supervisor. They were also not required to provide any details and the likes, transcripts and the final report will not reflect the subject's information such as their names. After scribbling the provided 
information, the tapes were kept in a confidential place, after the study has been completed and a report was written, the tapes would be totally destroyed.

\section{Role of the Researcher}

The researchers will facilitate the procedure of the study in order to have a smooth process. The researchers will duplicate the obtained records from IDI, peruse and examine it to unify points of ideas. They will inspect from the reaction of the members and identify the information that they gathered appropriately. Their discoveries will be exhibited to its brief explanation. They will do each undertaking in gathering and translating information from the composed writings, triangulate them and choose whether to acknowledge or deny the discoveries. To make it progressively truthful, they will blend and make an interpretation of the information into a general truth. With this, they will certainly know and become familiar with the encounters of a Home Economics - Cookery students.

\section{RESULTS AND DISCUSSION}

This chapter has been formulated to answer the research question keeping the literature review and research findings from the interviews in consideration.

Research Question 1: What is the effect of cooking as a hobby activity on Home Economics students, in the context of Maslow's Hierarchy of Needs?

The theory of Maslow (2016) was used for this question. In his classical hierarchy of needs, Maslow proposed that humans have five levels of needs that are arranged in a hierarchy. This means that as the needs in one level of the hierarchy are satisfied; the needs in the next level that is greatest in power or influence will appear and dominate human consciousness until that need is fulfilled. Maslow presented these needs in a hierarchy in order of prepotency from the base to the pinnacle. The needs described are as follows: physiological needs, 
secure needs, love and belongingness needs, esteem needs and self-actualization needs. Outlined in the following subsections are the needs proposed by Maslow as well as the extracted answers from the participants, analysis of data and related studies:

\section{Physiological Needs}

Satisfying physiological needs helps in sustaining the physical and biological requirements for human survival. If these needs are not met, a person cannot function. Hence, the sense of hunger signals a lack of components essential for normal life activities. All of the participants identified satisfaction of physiological needs as a motivation for cooking. In the interview extract, Participant A identified the need to satisfy the hunger of others rather than his own:

"When I cooked for example - for dinner, I make sure that I prepared enough food to fill the tummy of each family member. I...I...I normally don't eat what I make. What matters most when I cook is that when I see others achieve satiety in the food I made, I am happy and motivated to do other things."

These findings agree with those of Mills et al. (2017), concerning the meaning adult participants from the North East of England attribute to cooking practices and experiences. Providing healthy nourishment and satisfying hunger for the participant's family members, was found to be one of the fundamental motivations for cooking. Hamburg, Finkenauer, and Schuengel (2014) too had found that sharing of food resources to children as well as the use of food as a support behavior was one of the motivations of mothers for cooking.

According to Maslow (2016), the satisfaction of physiological needs is usually associated in the society with money. Money is used as a means to be used to satisfy other motives. Thus, it is what money can buy, not money itself, that satisfies one's physiological needs. In the interview extract, Participant B identified how cooking helps in generating monetary value:

"Most of the time, I traded the products I made from cooking. Uhm... For example, I can generate extra income from making munchkins, kakanin and lunch viands. The money I get from this ... uhm ... is used to buy foods and personal 
clothes. Sometimes, I ... I used the money to pay for the rental fee of the house I stayed. I am motivated to cook, not for the money I take ... to survive in this life."

These statements agree with those of Regnier, Dugre, Darcel, and Adamiec (2018), which found out that majority of the 28 social workers of Magny, Paris identified money generated from cooking as a lever to buy the basic needs of their family such as food and clothing. These participants, who did not own any business, included cooking as their hobby to fulfill their family's basic needs. Moreover, Reicks, Trofholz, Stang, and Laska (2014) studied the impact of cooking and home food preparation among adults. Their findings stated that the central motivation of adults from household cooking was not the money generated, but the desire of the cooker to buy the needs of their family members. In another response of Participant $\mathrm{C}$, he said that:

"Money does not matter most of the time. I am just happy that they [members of the family] get what they want. Seeing them happy keeps me motivated to cook and earn more money."

\section{Secure needs}

A person's need for security includes safety and protection from physical and emotional harm (Maslow, 2016). Secure needs are activated after physiological needs are met. They are the needs for freedom from threat, danger, or deprivation, and involve self-preservation.

All of the participants referred to the sense of control they feel while cooking. Although we could not search a specific reference cited by Maslow to the relation between a sense of control and sustaining the need for security, Maslow's detailed report of what constitutes a secure environment clearly proposes such relationship. It appears that people's attempt to gain control of their environment is, in Maslow's terms, their effort to create a steady, familiar environment, and hence promote their

sense of security. Control in cooking may come in many ways. One is the control of the space.

From the interview extracts, it is clear that for most of the participants, gaining the control of the kitchen and of all its materials and equipment while 
cooking is a vital ingredient in their joy of cooking. When asked, most of the participants urged that they find it hard to share with other people their cooking space and sometimes even the entire kitchen. It seems that it is very noteworthy for them to control and dictate the entire cooking experience. Participant $C$ articulates the need to control the kitchen space:

"When I cook, I make sure that the kitchen is all mine. When someone ... uhm ... for example my younger brother, comes to the washing area to wash his hand, I get distracted and stopped my work. When someone wants to help me, I allow them if they insist, but I make sure that I have enough space to prepare the food I want."

Participant B describes the process of cooking as a symphony orchestra in which he commands the entire experience:

"While cooking, there is a sense of harmony among the materials and foods. It seems that I can control what I want to do ... I consider myself as the leader of my symphony orchestra for example. "

\section{Love and belongingness needs}

Social needs are dominant for individuals in striving for meaningful relation with others for the sake of happiness. This is an important social or affiliation motive, which drives people to seek contact with other people and to create satisfying relations with them. To be a human being, somebody must have other people around them. Maslow (2016) explained that people have an innate need for affection and love that can be satisfied only by other people. Thus, individuals must affiliate with others, and identify himself or herself with one or more likeminded individuals. When he or she identifies with someone else, they learn to perceive part of the world as that person presumable does.

For all of the participants, the family home, during childhood, is where cooking was first encountered. All participants speak not only of this initial contact but also of the immediate social interaction and social context it inspired. Occasionally, the references are made in passing and resist too deep an interpretation but more often than not, they are more considered comments and 
are important in highlighting familial closeness, affection and love, the denial of which, Maslow (2016) sees as basic in the picture of maladjustment. Participants $A$ and $B$ draw attention to this point very early on in their interviews. They both note a physical, almost umbilical, connection between cooking and contact with their fathers:

"First cooking I can remember doing was ... uhm ... if this isn't too much of a cliché, embracing with the left arm of my father ... uhm ... cooking recipes, the names of which l've completely forgotten."

Participant B, who suggests a significant personal influence of cooking notes the following:

"Cooking has been part of my life since I was just a lad on my father's arm. Our family owned a catering service, which I would cook with my father until I was able to continue on my own".

Participant $C$ also notes that his first encounter with cooking itself was with family, his comments again highlight the conflation of family - particularly family closeness - and cooking:

"The first cooking I experience was ... when I was probably like thirteen years old and so...so I wasn't that attentive. I can remember my uncle cooking adobo and kind of watching him and stirring the menu."

The elder figures in some of the above extracts (parents of the participants) are clearly involved in the concept of Juul (2012) stating that who you cook with ... influences how you cook. They are guiding their charges in various ways: making suggestions or taking control when steps in cooking became too difficult for a child to negotiate. The children will also, of course, have played this cooking scenario: asking questions, making suggestions and sometimes taking (back) control. If any of the cooking were in need of the help of the family members such as their father (it was not always noted in the above examples), then the adults undoubtedly 'selfhandicapped' (Juul, 2012) in an attempt to provide their children with a sense of achievement and esteem. Both parent and child are locked into a feedback loop of loving interaction, facilitated by cooking. This interaction, then, is uniting these family members, satisfying their hunger for contact, intimacy and belongingness 
that can only be gained from another human being (Maslow, 2016). For all of the participants, in fact, cooking played an important part in their younger years, uniting their families and creating environments which allowed positive, often loving, relationships to flower, something Maslow notes as essential, with people determined to gain relations with people in general - for a place in a group or family (Maslow, 2016).

Generally, participants did not directly relate their yearning to cooking as a way of satisfaction of love needs. Yet different statements they made confirm to such a relationship, more conspicuously between cooking and maintaining close social ancestral relationships and their belonging to ethnic and long tradition. All of the participants said that cooking help them to maintain their familial and social networks. It is the sitting together, the unnoticed bonding that is being reinforced while eating as a family that pushed the Participant B to prepare those lavish dishes for his family:

"What stood behind these foods was the warmth, the sitting together, the feeling that I am devoted to my family ... this really unites the family."

For Participant A, as for many others too, cooking is a mean for satisfying love and belonging needs. In his words:

"In the long run after I cooked, we all eat and enjoy it very much, and then it is our time to spend together. Food is one way of creating get-togethers."

These findings concur with those of Dunbar (2017), who found out that cooking helps uphold the cookers' social network and their place in this network, as social congregations are organized around their cooking. The study further revealed that the more often people eat with others, the more likely they are to feel glad and satisfied with their lives.

The need for belonging also includes one's wish for the sense of being part of a large ancestral and cultural tradition (Maslow, 2016). One of the important characteristics of tradition and ethnicity is the particular way of food cooking and dining. For the two of the participants, cooking was an important way of reconnecting to their ethnic roots. For Participant $A$, cooking was a way of keeping 
his tradition alive, evoking fond memories of his father and of those traditional recipes and tastes:

"My father really loves to cook. I can still remember the tastes. My grandmother too, was a cook of many delicacies. The most favorite food she ever cooked was ginataang isda. Those delicacies are evident in the foods I cooked in our house in the present days."

A sense of accountability is evident in these words of relinquishing responsibilities, a tradition, knowledge, or practice to another. Geremew, Gedefaw, Dagnew, and Jara (2014) has found that $95 \%$ of the participants of households use traditional recipes to strengthen their relation to their family tradition and Chen (2013) report that United States women's main motivation for cooking the way they do was to uphold their cultural identity. The participants also emphasized their feeling of responsibility to pass the tradition of their family. They attested to the significance of that sense of belonging and wanted to pass that on. Rhodes et al. (2014) too has found that the participants perceive cooking as an important network for preserving and transmitting the cultural tradition.

\section{Esteem Needs}

Satisfaction of love and belongingness needs triggers the emergence of the esteem need (Maslow, 2016). In this stage of need gratification, persons also want to be esteemed, by the people they are in contact with, as well as by themselves: they want to know that they are capable of achievement and success. Maslow (2016) classifies the need for self-esteem into two categories. First, it is internal respond against them dealing with getting competence, self-confidence, adequacy, autonomy, and freedom. Thus, individuals are sure that they have selfesteem and are able to cope with the obstacles in life. Second is achievement. In this case, individuals need appreciations over what they to do. Individuals will feel confident, forceful, capable, and valuable, if need for self-esteem is satisfied. On the contrary, individuals will feel frustrated and upset, if this need is not satisfied. The result of it has a strong effect on individual development in facing his coming 
life, for they feel inferior, weak, worthless, and hopeless to accept a real life. They feel pessimistic with other people.

Others' gratitude of their cooking is something that all the participants mentioned as a very significant motivating factor making it the most predominant one. Without the feedback, Participant A says, he would not enjoy cooking:

"When I prepare food in the house, let's say ... uhm ... for example dinner, I easily get disappointed after dining if any of my family members would not appreciate the food I cook. I always see to it that I receive enough praise ... adorations from the food I serve ... so that I can gain confidence in the next meal I will be preparing."

Participant B was more explicit:

"The responses from other people such as ... my family, friends ... I desire for it ... without appreciation, I felt dissatisfied of the things I do."

Analyzing the content of the participants' interview extracts, it comes clear that in addition to enjoying others' gratitude of their cooking skills, it put them in the point of attention. This appears to be no less important, although not directly said, it was implied by all of the participants. Farmer, Leonard, and Ross (2018) reports similar findings. The study revealed that cooking extends beyond the nutritional value it gives, it puts the cook in the focus, giving him the reward of appreciation, among others.

Furthermore, all of the participants referred to the fact that being in that place enhance their sense of self-esteem. They mentioned in this regard that feeling good about their talent in cooking is an indispensable motivating force and a basic element in their enjoyment of cooking. For instance, Participant $\mathrm{C}$ describes how cooking strengthens him in times of stress:

"If I am down sometimes ... I get my strength back through cooking. I feel lively every time I cook. There is something in it that drives my inner spirit. I know I am not that smart, rich, handsome [laugh] ... but I believe I am a good cooker ... this I considered as my talent ... gives me the optimism and most importantly, the confidence to anyone." 
Lewis (2016) found out that majority of the 658 people in New York believe that cooking increases self-confidence, and self-image. Furthermore, the participants feel more enthusiastic about their pursuits the next day.

\section{Self-actualization needs}

The highest and the last class of needs on the hierarchy is self-actualization. It is also the weakest because all other needs on the hierarchy must be rather well satisfied in order for this class of needs to emerge. Self-actualization needs go beyond the esteem needs in a significant fashion. According to Maslow (2016), the self-actualized persons are those who desire to become more and more what one is, to become everything one is capable of becoming. He further clarifies that it is not easy to reach this degree and to fulfill this need, for there are a number of troubles that must be passed through.

First, it is internal trouble dealing with misunderstanding, doubt, and even individuals' fear feeling to express their own potential. Further, the challenge of need for self-actualization comes from external or society. For instance, participant C utters:

"I am sometimes stereotyped by others ... they say why I love cooking even

if men are for physically hard jobs. Some judge me for not following the community's ideal hobby for man. There were times that I feel shy when someone asks me what is my hobby and what strand I am currently taking ... I just don't know ... but I still continue what I love ... it just makes me sad knowing these preconceptions."

Garine (2011) supported this statement contending that society has a tendency to personalize individuals' condition like character, talent, and potential. Moreover, he added that the society has a cultural stereotype about how an individual is called "Gentlemen" or "not".

The last trouble over self-actualization is the negative effect from selfsecurity. Individual development process needs to be responsible to take a risk, make a mistake and get rid of the unconstructive habit. As a result, the 
achievement of self-actualization not only needs a conducive environment, but also contemporaneous individuals' experience. Participant B says:

"I always strive for new combination of recipes for a given menu... for example, I mix different amounts of ingredient to alter the taste of food. Aside from that ... uhm ... I attempt to cook other dishes and try to be creative ... I make sure I am not stuck in a particular dish ... in a particular ingredient. If I let others taste my new food and get their approval, I get satisfied and explore new things again."

Participant A further adds:

"I am a competitive individual... I always make sure to be on top. In terms of cooking, for example, to remain on top, I explore new dishes and new ingredients ... after I select the best combination, I feel satisfied. When I cook a new dish I never cooked before, it seems like I am doing an experiment."

Participants $A$ and $B$ refer to this process of cooking as "spontaneous and creative cooking" which ultimately result on peak experiences of satisfaction and happiness. It appears that this process affords him a sense of enjoyment, control and satisfaction. Several scholarly literatures have been circulated pointing out that the activity of cooking is perceived as an activity that promotes the expression of one's creativity (Beghetto, Kaufman, \& Hatcher, 2016; McCabe \& Malefyt, 2013). And yet no actual plotting of the ways in which the cooker may understand his creativity was performed.

Participant $B$ affirms that through cooking, he is able to accept himself and become problem-centered:

"Cooking helps me express who I am ... what I cook reflects on my personality, my thoughts ... my ambitions most importantly. I learn to accept that this is my life ... in fact, I believe I have a big future in doing this. Through cooking and going to school to hear lessons about the strand I am currently taking, I can help my family rise against poverty."

This concur to the findings of Cherry (2010), which enumerate the characteristics of self-actualized individuals. Among the characteristics, she noted that acceptance of self, others and nature and problem-centeredness are the 
notable typologies of individual in order to realize and use his full potential, capacities, and talents.

Based on the interview extracts, 14 themes were generated. These themes were categorized into each of the Maslow's five categories of needs. All of these themes were found fit to Maslow's hierarchy of needs. Presented in Table 1 are the 14 initial themes, their recurrence and grouping into conceptual themes.

As shown in the table, the greatest number of themes generated were conceptualized from self-actualization needs. These were the following: stereotypes and cooking, acceptance of self, problem-centeredness, creativeness, spontaneity, and peak experiences. Of all the initial themes, cooking to connect with family and to gain self-confidence were stated by all of the participants (100\%). The statements about cooking to connect with family were verbalized most of the interview time at $19.23 \%$.

Table 1. Thematic Analysis

\begin{tabular}{|c|c|c|c|}
\hline $\begin{array}{l}\text { Initial theme } \\
(\mathrm{N}=14)\end{array}$ & $\begin{array}{l}\text { Recurrence of } \\
\text { initial theme } \\
\text { among } \\
\text { participants } \\
(\mathrm{N}=3)\end{array}$ & $\begin{array}{l}\text { Conceptual } \\
\text { theme }(\mathrm{N}=5)\end{array}$ & $\begin{array}{l}\text { Recurrence of } \\
\text { statements among } \\
\text { all statements } \\
\text { analyzed }(\mathrm{N}=26)\end{array}$ \\
\hline $\begin{array}{l}\text { Cooking for } \\
\text { satiation of others }\end{array}$ & $33.33 \%$ & \multirow[t]{2}{*}{$\begin{array}{l}\text { Physiological } \\
\text { needs }\end{array}$} & $3.85 \%$ \\
\hline $\begin{array}{l}\text { Cooking to } \\
\text { generate money }\end{array}$ & $66.67 \%$ & & $7.69 \%$ \\
\hline Sense of control & $66.67 \%$ & Secure needs & $7.69 \%$ \\
\hline $\begin{array}{l}\text { Cooking to } \\
\text { connect with } \\
\text { family }\end{array}$ & $100 \%$ & \multirow[t]{2}{*}{$\begin{array}{l}\text { Love and } \\
\text { belongingness } \\
\text { needs }\end{array}$} & $19.23 \%$ \\
\hline $\begin{array}{lr}\text { Cooking } & \text { to } \\
\text { preserve familial } \\
\text { tradition }\end{array}$ & $33.33 \%$ & & $3.85 \%$ \\
\hline
\end{tabular}




\begin{tabular}{|c|c|c|c|}
\hline $\begin{array}{l}\text { Cooking to get } \\
\text { appreciation from } \\
\text { others }\end{array}$ & $66.67 \%$ & Esteem needs & $7.69 \%$ \\
\hline $\begin{array}{l}\text { Cooking to gain } \\
\text { self-confidence }\end{array}$ & $100 \%$ & & $11.54 \%$ \\
\hline $\begin{array}{l}\text { Cooking to regain } \\
\text { strength }\end{array}$ & $33.33 \%$ & & $3.85 \%$ \\
\hline $\begin{array}{l}\text { Cooking and } \\
\text { stereotypes }\end{array}$ & $33.33 \%$ & \multirow{6}{*}{$\begin{array}{l}\text { Self- } \\
\text { actualization } \\
\text { needs }\end{array}$} & $3.85 \%$ \\
\hline $\begin{array}{l}\text { Acceptance of } \\
\text { self }\end{array}$ & $33.33 \%$ & & $3.85 \%$ \\
\hline $\begin{array}{l}\text { Problem- } \\
\text { centeredness }\end{array}$ & $33.33 \%$ & & $3.85 \%$ \\
\hline Creativeness & $66.67 \%$ & & $7.69 \%$ \\
\hline Spontaneity & $66.67 \%$ & & $7.69 \%$ \\
\hline Peak experiences & $66.67 \%$ & & $7.69 \%$ \\
\hline
\end{tabular}

\section{Conclusion and Recommendation}

\section{CONCLUSION}

In conclusion, the needs of physiological, secure, love and belongingness, esteem, and self-actualization have an effect on the UIC Home Economic Student's perspective. Money is involved in physiological needs that are also essential when buying the ingredients used in cooking. The higher the money the students have, the higher the satisfaction in physiological needs. Additionally, the sense of control is included in the need for security. The learners highly appreciated those who respect their work since it is the only place that they find secure. We should give them space whenever they are inside the kitchen. Also in love and belongingness needs, they felt a deep connection whenever they are cooking. The bonding that they have with their family is what made them familiar 
with cooking. Moreover, the esteem needs cater to two categories: the internal response and the competence among others. The first one is that they should maintain high self-esteem when cooking in the kitchen. Another one is that they should be appreciated with their output to help them gain more self-esteem. Lastly, the self-actualization need goes beyond than what is self-esteem. It emphasizes that learners do everything to be better in the next output. They should feel a sense of satisfaction when cooking.

All these needs are significant for learners when cooking. They are the factors that build the needs of the students and is greatly affected of cooking as a hobby of Home Economics' class.

\section{RECOMMENDATION}

Maslow builds the hierarchy of needs for us to become knowledgeable about the feeling of other people as they cook. In particular, based on the survey results and it deliberations, the researchers' offers the following recommendations:

- Utilize bigger number of participants and they should not settle for 2-3 participants, to have a various amount of information from increasingly different partaker.

- Include those individuals that are not studying about cooking but know how to cook and compare them with those who have educational experience about cooking.

- Reduce the restrictions to be a partaker.

- Utilize those participants that is not a Home Economics students or of the University of Immaculate Conception. 


\section{REFERENCES}

Almas, R. (2006). Domestic dinner: Representations and practices of a proper meal among young suburban mothers. Journal of Consumer Culture, 6(2), 203- 228. Retrieved from file:///C:/Users/User/Downloads/cooking-andhierarchy-of-needs.pdf.

Beghetto, R. A., Kaufman, J. C., \& Hatcher, R. (2016). Applying Creativity Research to Cooking. The Journal of Creative Behavior, 50(3), 171-177. doi:10.1002/jocb.124

Chen, T. (2013). Homemade : an exploratory study on the impact of cooking on family relationships and cultural identity development. (1077). Retrieved from https://scholarworks.smith.edu/theses/1077

Cherry, K. (2010). Characteristics of self-actualized people common traits of selfactualized individuals. Retrieved from http://about.com/ selfactualizedcharacteristic.htm

Dunbar, R. (2017). Breaking Bread: the Functions of Social Eating (Vol. 3).

Farmer, N., Leonard, K., \& Ross, A. (2018). Psychosocial Benefits of Cooking Interventions: A Systematic Review. Health education \& behavior : the official publication of the Society for Public Health Education, 45(2), 167180. doi:10.1177/1090198117736352 
Frank G. Goble, The Third Force: The Psychology of Abraham Maslow (New York 1970)

p. 25

Retrieved

from https://pdfs.semanticscholar.org/031f/c3ac8c56cb2f0e8a89f8fa90f720dae 7d17d.pdf.

Garine, I. (2011). Views about food prejudice and stereotypes (Vol. 40).

Geremew, K., Gedefaw, M., Dagnew, Z., \& Jara, D. (2014). Current level and correlates of traditional cooking energy sources utilization in urban settings in the context of climate change and health, northwest Ethiopia: a case of Debre Markos town. BioMed research international, 2014, 572473-572473. doi:10.1155/2014/572473

Alipio, M. (2020). Predicting Academic Performance of College Freshmen in the Philippines using Psychological Variables and Expectancy-Value Beliefs to Outcomes-Based Education: https://doi.org/10.35542/osf.io/pra6z

A Path Analysis.

Alipio, M. (2020). Academic Adjustment and Performance among Filipino Freshmen College Students in the Health Sciences: Does Senior High School Strand Matter?. https://doi.org/10.35542/osf.io/xq4pk

Gleitman, H., Fridlund, A., \& Reisberg, D. (2011). Psychology ( $8^{\text {th }}$ edn). New York: WW Norton \& Company. Retrieved from https://www.interactiondesign.org/literature/article/maslow-s-hierarchy-ofneeds?fbclid=IwAR1sr9UWSMfMd0K3Rqg6YKAag7dUc0rwuCC v_ZxN2rt xaJ80s_jsgZWV7_0.

Gleitman ,Henry; Fridlund, Alan J. and Reisberg Daniel. Psychology. $6^{\text {th }}$ ed. New York: Norton \& Company, 2004 and Maslow, Abraham H. The Psychology 
of Science. Gateway Edition 1.95 ed. Chicago: Henry Regnery Company, 1969.

Retrieved

from

https://pdfs.semanticscholar.org/031f/c3ac8c56cb2f0e8a89f8fa90f720dae 7d17d.pdf.

Hamburg, M. E., Finkenauer, C., \& Schuengel, C. (2014). Food for love: the role of food offering in empathic emotion regulation. Frontiers in psychology, 5, 32-32. doi:10.3389/fpsyg.2014.00032

Hoffman, E. (1988). The right to be human: A biography of Abraham Maslow. Jeremy $P$. Tarcher, Inc. Retrieved from https://www.simplypsychology.org/maslow.html?fbclid=IwAR2IBI0x9bbVZj YeewlbdunLBblaENorBjzpaRg-Ycuj0Yewlgrs3BZBcHY.

Hofstede, G. H. (1980). Motivation, leadership and organization: Do American theories apply abroad?. Organizational Dynamics, 9(1), 42-63. Retrieved from https://www.pap.org.ph/sites/default/files/upload/pjp2014-47-1pp117-143-ilaganhechanovacopleyto-

bakit_ka_kumakayod_developing_a_filipino_needs_theory_of_motivation. pdf.

Juul, J. (2012). A Casual Revolution: Reinventing Video Games and Their Players.

Kenrick, D. T., Neuberg, S. L., Griskevicius, V., Becker, D. V., \& Schaller, M. (2010). Goal-Driven Cognition and Functional Behavior The FundamentalMotives Framework. Current Directions in Psychological Science, 19(1), 63-67. Retrieved from https://www.simplypsychology.org/maslow.html?fbclid=IwAR2IBI0x9bbVZj YeewlbdunLBblaENorBjzpaRg-Ycuj0Yewlgrs3BZBcHY.

Lewis, D. (2016). Feeling Down? Scientists Say Cooking and Baking Could Help You Feel Better. Retrieved from https://www.smithsonianmag.com/smart- 
news/feeling-down-scientists-say-cooking-and-baking-may-help-you-feelbetter-180961223/

Lockwood, N. R. (2010). Motivation in today's workplace: The link to performance. Society for Human Research Management Research Quarterly, 2, 1-9. Retrieved from https://www.pap.org.ph/sites/default/files/upload/pjp201447-1-pp117-143-ilaganhechanovacopleytobakit_ka_kumakayod_developing_a_filipino_needs_theory_of_motivation. pdf.

Maslow, A. (2016). A Theory of Human Motivation.

Maslow, A., (1943). A theory of human motivation. Psychological Review. 50, 4, 370-96. Retrieved from https://mpra.ub.unimuenchen.de/50987/1/MPRA_paper_50987.pdf?fbclid=IwAR2gVZzwFuZ VmURvJca6iMIUZuCr35v2_HgjseGAgFU9W0MSz5e5FhKneo.

Maslow, A. H. (1943). A theory of human motivation. Psychological Review, 50(4), 370-396. Retrieved from https://www.statisticssolutions.com/theoretical-spotlight-maslowshierarchy-of-needs/.

Maslow, A. H. (1943). A Theory of Human Motivation. Psychological Review, 50(4), 370-96. Retrieved from https://www.simplypsychology.org/maslow.html?fbclid=IwAR2IBI0x9bbVZj YeewlbdunLBblaENorBjzpaRg-YcujOYewlgrs3BZBcHY.

Maslow, A. H. (1954). Motivation and personality. New York: Harper and Row. Retrieved from https://www.simplypsychology.org/maslow.html?fbclid=IwAR2IBI0x9bbVZj YeewlbdunLBblaENorBjzpaRg-Ycuj0Yewlgrs3BZBcHY.

Maslow, A. H. (1962). Toward a Psychology of being. Princeton: D. Van Nostrand Company. Retrieved from 
https://www.simplypsychology.org/maslow.html?fbclid=IwAR2IBI0x9bbVZj YeewlbdunLBblaENorBjzpaRg-Ycuj0Yewlgrs3BZBcHY.

Maslow, A. H. (1971). The farther reaches of human nature. Harmondswort, Middlesex: Penguin Books. Retrieved from file:///C:/Users/User/Downloads/cooking-and-hierarchy-of-needs.pdf.

Maslow, A. H. (1970a). Motivation and personality. New York: Harper \& Row. Retrieved from https://www.simplypsychology.org/maslow.html?fbclid=IwAR2IBI0x9bbVZj YeewlbdunLBblaENorBjzpaRg-Ycuj0Yewlgrs3BZBcHY.

Maslow, A. H. (1970b). Religions, values, and peak experiences. New York: Penguin. (Original work published 1966) Retrieved from https://www.simplypsychology.org/maslow.html?fbclid=IwAR2IBI0x9bbVZj YeewlbdunLBblaENorBjzpaRg-Ycuj0Yewlgrs3BZBcHY.

Maslow, A. H. (1987). Motivation and personality (3 ${ }^{\text {rd }}$ ed.). Delhi, India: Pearson Education. Retrieved from https://www.simplypsychology.org/maslow.html?fbclid=IwAR2IBI0x9bbVZjYeewl bdunLBblaENorBjzpaRg-YcujOYewlgrs3BZBcHY

McCabe, M., \& Malefyt, T. (2013). Creativity and cooking: Motherhood, agency and social change in everyday life (Vol. 15).

Mills, S., White, M., Wrieden, W., Brown, H., Stead, M., \& Adams, J. (2017). Home food preparation practices, experiences and perceptions: A qualitative interview study with photo-elicitation. PloS one, 12(8), e0182842e0182842. doi:10.1371/journal.pone.0182842

Regnier, F., Dugre, M., Darcel, N., \& Adamiec, C. (2018). Providing a Smart Healthy Diet for the Low-Income Population: Qualitative Study on the Usage 
and Perception of a Designed Cooking App. JMIR Mhealth Uhealth, 6(11), e11176. doi:10.2196/11176

Reicks, M., Trofholz, A. C., Stang, J. S., \& Laska, M. N. (2014). Impact of cooking and home food preparation interventions among adults: outcomes and implications for future programs. Journal of nutrition education and behavior, 46(4), 259-276. doi:10.1016/j.jneb.2014.02.001

Rhodes, E., Dreibelbis, R., Klasen, E., Naithani, N., Baliddawa, J., Menya, D., . . . Checkley, W. (2014). Behavioral Attitudes and Preferences in Cooking Practices with Traditional Open-Fire Stoves in Peru, Nepal, and Kenya: Implications for Improved Cookstove Interventions (Vol. 11).

Schacter, D. L., Gilbert, D. T., \& Wegner, D. M. (2011). "Human needs and selfactualization". Psychology, 486-487, Worth, New York. Retrieved from https://www.interaction-design.org/literature/article/maslow-s-hierarchy-ofneeds?fbclid=IwAR1sr9UWSMfMd0K3Rqg6YKAag7dUc0rwuCCv_ZxN2rt xaJ80s_jsgZWV7_0.

Sidenvall, B., Nydahl, M. \& Fjellstrom, C. (2000). The meal as a gift: The meaning of cooking among retired women. Journal of Applied Gerontology, 19, 405423. Retrieved from file:///C:/Users/User/Downloads/cooking-andhierarchy-of-needs.pdf.

Sirgy, M. Joseph: 1986, 'A quality-of-life theory derived from Maslow's developmental perspective', American Journal of Economics and Sociology 45(3), pp. 329-342. $\quad$ Retrieved from https://link.springer.com/article/10.1023/A:1006921107298

Starr- Sered, S. (1988). Food and holiness: Cooking as sacred act among Middle Eastern Jewish women. Anthropological Quarterly, 61(3), 129-139. Retrieved from file:///C:/Users/User/Downloads/cooking-and-hierarchy-ofneeds.pdf.

Tay, L., \& Diener, E. (2011). Needs and subjective well-being around the world. Journal of Personality and Social Psychology, 101(2), 354-356. Doi:10.1037/a00 Retrieved from https://www.simplypsychology.org/maslow.html?fbclid=IwAR2IBI0x9bbVZj YeewlbdunLBblaENorBjzpaRg-YcujOYewlgrs3BZBcHY. 
Wicker, Frank W., G. Brown, James A. Wiehe, Anastasia S. Hagen and J. Lynn Reed: 1993, 'On reconsidering Maslow: An examination of the deprivation/ domination proposition', Journal of Research in Personality 27, pp. 118133. Retrieved https://link.springer.com/article/10.1023/A:1006921107298

Wrangham, R.W., Jones, J.H., Laden, G., Pilbeam, D. \& Conklin- Brittain, N. (1999). The raw and the stolen. Current Anthropology, 40(5), 567-594. Retrieved from file:///C:/Users/User/Downloads/cooking-and-hierarchy-ofneeds.pdf.

Wulff, D. M., \& Maslow, A. H. (1965). Religions, Values, and PeakExperiences. The Journal of Higher Education, 36(4), 235. Retrieved from https://www.simplypsychology.org/maslow.html?fbclid=IwAR2IBI0x9bbVZj YeewlbdunLBblaENorBjzpaRg-Ycuj0Yewlgrs3BZBcHY

Yao, K., Franco, E., \& Hechanova, R. (2005). Rewards that matter: What motivates the Filipino employee?. In R. Hechanova \& E. Franco (Eds.), The way we work (pp. 44-62). Quezon City: Ateneo de Manila University Press. Retrieved from https://www.pap.org.ph/sites/default/files/upload/pjp201447-1-pp117-143-ilaganhechanovacopleytobakit_ka_kumakayod_developing_a_filipino_needs_theory_of_motivation. pdf.

Zusman- Asher, R. (2007). The relation between pastime and perceived freedom, intrinsic motivation, pastime experience and pastime contentment [Hebrew]. A master's thesis, Tel Aviv University. Retrieved from file:///C:/Users/User/Downloads/cooking-and-hierarchy-of-needs.pdf. 